\title{
Temporal distribution of the potentially toxic diatom Pseudonitzschia australis at a coastal site in Southern California
}

\author{
C. B. Lange ${ }^{1}$, F. M. H. Reid ${ }^{2}$, M. Vernet $^{3}$ \\ ${ }^{1}$ Scripps Institution of Oceanography, Geological Research Division, La Jolla, California 92093-0215, USA \\ ${ }^{2}$ Scripps Institution of Oceanography, Marine Life Research Group, La Jolla, California 92093-0218, USA \\ ${ }^{3}$ Scripps Institution oi Oceanography, Marine Research Division, La Jolla, California 92093-0218, USA
}

\begin{abstract}
Species of the genus Pseudonitzschia have been implicated in outbreaks of domoic acid (DA) toxicity off the coasts of North America. This led us to look at the historical (1930-1939, 1967, 1983, 1991-1993) occurrence and abundance of these species off the Scripps Institution of Oceanography pier, Southern California, USA, with special emphasis on $P$. australis Frenguelli for which we have the most complete data. The organism occurs sporadically in high numbers $\left(10^{4}\right.$ to

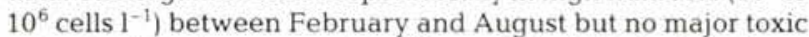
episodes have been reported. The periods of high abundance were associated with intrusion of cool, high-nutrient waters probably related to upwelling events. To date, there have been no major DA outbreaks in the Southern California Bight.
\end{abstract}

KEY WORDS: Pseudonitzschia australis - Toxic diatoms . Domoic acid · Southern California

In light of new information on potentially toxic diatoms of the genus Pseudonitzschia (U.S. Food and Drug Administration 1992) we are interested in extending our knowledge of these organisms in order to assess the likelihood of toxic occurrences in Southern California. The importance of the group in this area has been noted since Allen's work in the 1920s to 1940s (e.g. Allen 1928, 1936, 1940, Reid et al. 1985). These diatoms have been associated with the production of domoic acid (DA), a neuroexcitatory amino acid known to be produced by 2 rhodophycean macroalgae (Maeda et al. 1986), and recently by at least 3 Pseudonitzschia species, P. australis Frenguelli (= Nitzschia pseudoseriata Hasle), P. pungens f. multiseries (Hasle) Hasle $(=N$. pungens $\mathrm{f}$, multiseries Hasle) and P. pseudodelicatissima (Hasle) Hasle $(=N$. pseudodelicatissima Hasle); see Hasle (1993) for recent nomenclatural changes. It is toxic to humans through the consumption of DA-contaminated seafood (Subba Rao et al. 1988, Bates et al. 1989, Bird \& Wright 1989), The resulting syndrome, severe gastrointestinal and neurologic illness, has been named 'Amnesic Shellfish Poisoning'.

Toxin production by diatoms was undetected before 1987 when a bloom of Pseudonitzschia pungens f. multiseries occurred in Cardigan Bay, Canada, causing toxicity in cultivated mussels (e.g. Subba Rao et al. 1988, 1989, Addison \& Stewart 1989, Todd 1989). There was a recurrence in 1988 (Smith et al. 1989). During July to October 1988 a toxic bloom of P. pseudodelicatissima was reported from the Bay of Fundy, Canada, and DA was detected in softshell clams and blue mussels (Martin et al. 1990). In early September 1991, DA produced by $P$. australis was responsible for the death or sickness of pelicans and cormorants in Monterey Bay, California (Buck et al. 1992, Fritz et al. 1992, Garrison et al. 1992, Work et al. 1993). Until January 1992 Malibu Beach, USA, was the southernmost location at which DA had been positively identified in bivalve shellfish; by May 1992 small amounts of DA (2.2 ppm; alert level is $20 \mathrm{ppm}$ ) were detected in mussels collected from the Scripps Institution of Oceanography (SIO) pier (California Department of Health Services 1992).

The Pseudonitzschia species implicated in these reports occur sporadically off the SIO pier $\left(32^{\circ} 50^{\prime} \mathrm{N}\right.$, $\left.117^{\circ} 10^{\prime} \mathrm{W}\right)$. The aim of this work is to summarize and update the temporal distribution and abundance of the potentially toxic species $P$. australis for which we have the best data.

Material and methods. Our observations of Pseudonitzschia australis in samples collected from the SIO pier include the years 1990 to 1993 . From 18 October 1990 to 26 July 1991 Niskin bottle samples were collected weekly; the sampling interval was increased to semiweekly from 21 February 1992 to 11 June 1993. Aliquots of $50 \mathrm{ml}$ were analyzed by the Utermöhl method (Utermöhl 1958). 
In order to obtain historical information about the occurrence of Pseudonitzschia species we examined phytoplankton data and samples collected at the SIO pier by W. E. Allen in 1930 to 1939 (Allen 1940). His counts in Sedgewick-Rafter cells were based on aliquots of 11 settled water. We also compiled diatom abundance information for periods in 1967 and 1983 from work already published by Reid et al. (1970, 1985). Abundance data refer to counts of single cells with protoplasm, but length of chains and empty cells were also noted in recent analyses.

Light and scanning electron microscopy were used for species identification (Hasle 1965) for all samples. This showed that Allen lumped together Pseudonitzschia australis and wide cells of $P$. pungens under the name 'Nitzschia seriata', and also verified the occurrence of a third species, $P$. pseudodelicatissima.

Nutrient and temperature data for the period 1990 to 1993 were obtained from the Marine Life Research Group (MLRG) time series which is in progress at the SIO pier. Earlier data, for temperature only, can be found in Reid et al. (1970, 1985) and Tont (1986).

Results and discussion. The large body of phytoplankton data collected by W. E. Allen resulted in quantitative information on diatoms and dinoflagellates (summary in Allen 1928, 1936, 1940, 1941). Maxima of 'Nitzschia seriata' ranged between $10^{4}$ and $10^{6}$ cells $1^{-1}$ and occurred in all years from 1930 to 1939 with the exception of 1931 and 1935. Relative abundances were high (representing 25 to $71 \%$ of total diatoms). The data show (1) 3 periods during the year when ' $N$. seriata' becomes abundant: February and/or March, April and/or May, and June or July or August, each lasting ca 3 to $7 \mathrm{~d}_{i}(2)$ that ' $N$. seriata' and total diatom abundances fluctuate concurrently; (3) the large interannual variation; and (4) the lack of an autumn peak, common in other areas of the west coast of the United States, such as Monterey Bay (Bolin \& Abbott 1963, Buck et al. 1992). Data for 1930, 1933 and 1939 are illustrated in Fig. 1 in order to show this seasonal pattern.

In 1967 Pseudonitzschia australis, originally identified as Nitzschia sp. 'large', showed maximum numbers on the order of $10^{4}$ cells $1^{-1}$ in mid-May, June and early August. After the August peak there was a sudden decline and a dinoflagellate bloom ('red tide') of Gonyaulax polyedra developed (Reid et al. 1970, Goodman et al. 1984). In 1983 N. seriata 'group' (probably including $P$. australis and $P$. pungens) was most abundant in March-April and June, although the numbers were an order of magnitude lower $\left(10^{3}\right.$ cells $\left.\mathrm{I}^{-1}\right)$ than those reported before, possibly due to El Niño

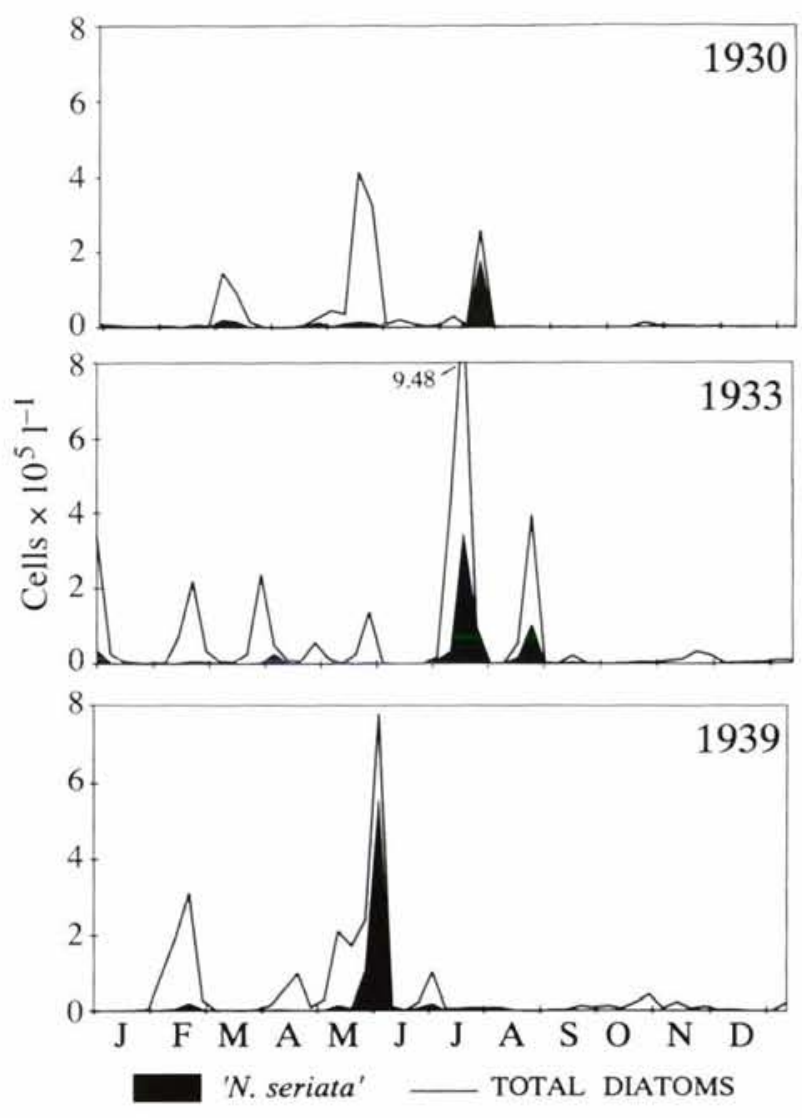

Fig. 1. Example of Allen's data (Tont 1986) for the SIO pier: total diatom and 'Nitzschia seriata' abundances (cells $\times 10^{5} \mathrm{I}^{-1}$ ) for 1930, 1933 and 1939

conditions (e.g. suppressed coastal upwelling; Reid et al. 1985). In mid-March 1991 a major bloom of $P$. australis $\left(10^{6}\right.$ cells $1^{-1}$, representing $57 \%$ of total diatoms) was recorded (Fig. 2). The 1992 samples showed a late February/early March peak of the order of $10^{4}$ cells $1^{-1}$ followed by another in early July exceeding $10^{4}$ cells $1^{-1}$.

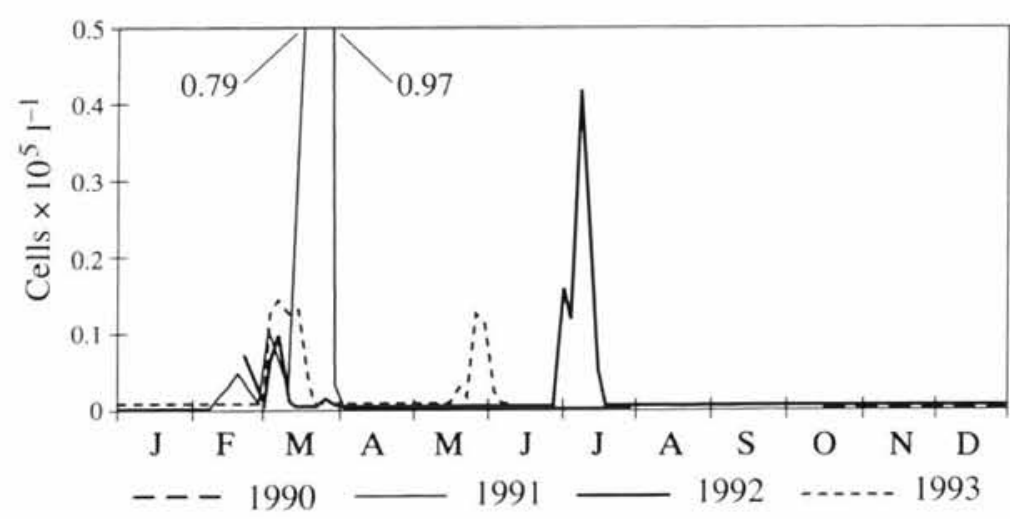

Fig. 2. Pseudonitzschia australis. Abundance at the SIO pier (cells $\times 10^{5} 1^{-1}$ ) from 18 October 1990 to 26 July 1991 and from 21 February 1992 to 11 June 1993. Dashed line: 18 Oct-31 Dec 1990; thin solid line: 1 Jan-26 Jul 1991; thick solid line: 21 Feb-31 Dec 1992; dotted line: 1 Jan-11 Jun 1993 
The latter was followed by a dinoflagellate bloom of Gymnodinium flavum (F. M. H. Reid unpubl. data). In 1993 there was a 3 to 4 d period in March when P. australis occurred though in small numbers (Fig. 2); other Pseudonitzschia species, $P$. pungens f. pungens and P. pseudodelicatissima, were more numerous. There was a similar occurrence in late May/early June $\left(10^{4}\right.$ cells $\left.\mathrm{l}^{-1}\right)$, concurrently with a Gonyaulax polyedra 'red tide' (F. M. H. Reid unpubl. data).

The 1991 Pseudonitzschia bloom consisted mostly of single cells, and in 1992 and 1993 chains of up to 16 cells were more common.

In Monterey Bay Pseudonitzschia australis abundances also showed a seasonal pattern, the highest numbers being in excess of $6 \times 10^{5}$ cells $1^{-1}$ in November 1991 (Buck et al. 1992).

The waters at the pier during the major Pseudonitzschia australis peaks were somewhat colder than during the days immediately preceding them; this was especially evident in June 1992 when the temperature dropped from 18.6 to $14.9^{\circ} \mathrm{C}$. In every case, there was a small nutrient $\left(\mathrm{NO}_{3}\right.$ and $\left.\mathrm{SiO}_{4}\right)$ input a few days before the abundance peak (compare Figs. $2 \& 3$ ). This sug-
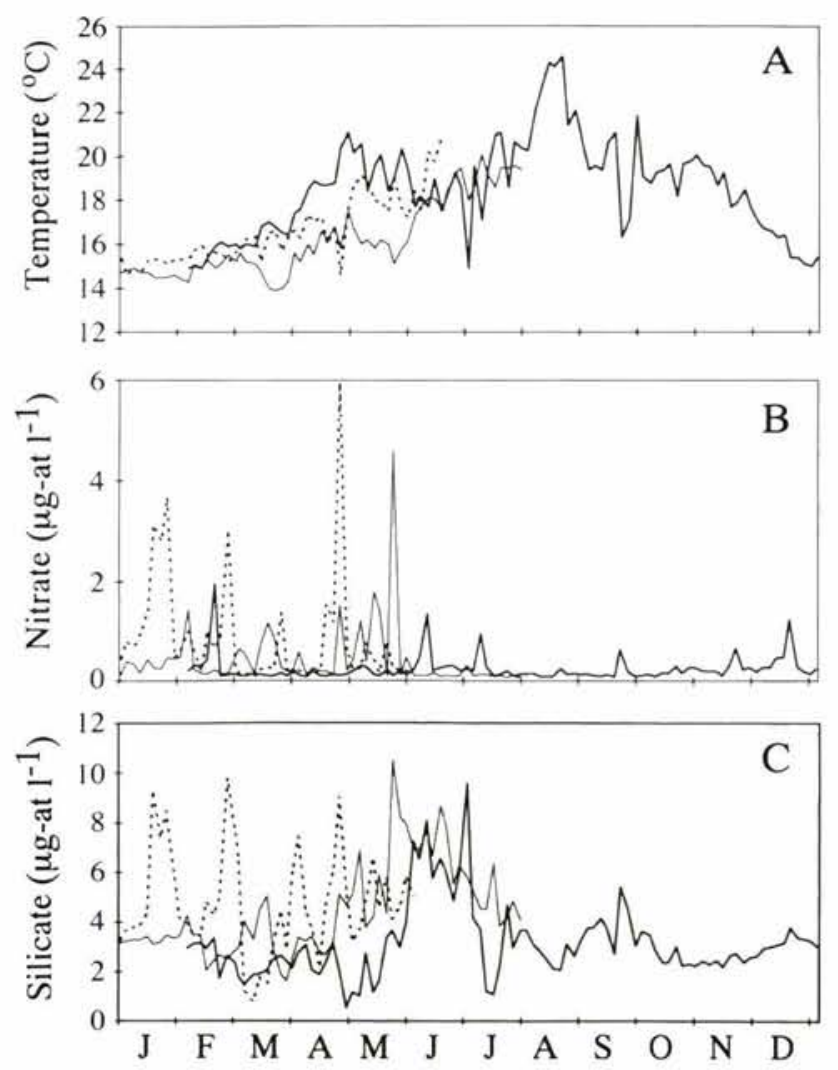

Fig. 3. (A) Temperature $\left({ }^{\circ} \mathrm{C}\right) ;(\mathrm{B}, \mathrm{C})$ nutrient data $\left(\mu \mathrm{g}\right.$-at. $\left.\mathrm{1}^{-1}\right)$ at the SIO pier for 1991, 1992 and 1993. Thin solid line: 1 Jan26 Jul 1991; thick solid line: 21 Feb-31 Dec 1992; dotted line: 1 Jan-11 Jun 1993 gests that the periods of high abundance are associated with intrusion of cool, high-nutrient waters probably related to upwelling events. Such events at the SIO pier usually occur in spring and are of short duration (see review in Jackson 1986). Internal tidal bores have also been implicated to explain the drops in surface temperatures at the SIO pier during summer. They have been correlated with increases in phytoplankton numbers and biomass (Pineda 1991). In Monterey Bay, P. australis was positively correlated with temperature (mostly $\geq 14^{\circ} \mathrm{C}$ ), though many periods of high abundance were at times of weak upwelling (Buck et al. 1992, Garrison et al. 1992). In contrast we found warm temperatures at the SIO pier $\left(\geq 18^{\circ} \mathrm{C}\right)$ to be associated with the dinoflagellate bloom of Gymnodinium flavum.

The time series we have collected, together with the historical information, indicate that Pseudonitzschia australis has been a regular and abundant component of the phytoplankton off Southern California, particularly in the spring and early summer. Although cell concentrations reach levels equivalent to those seen in Monterey Bay at the time of the 1991 severe DA outbreak, toxic episodes related to massive occurrences have not been reported. The small amounts of DA identified in mussels in May 1992 did not coincide with a high P. australis abundance in the water column (Fig. 2), and the large peak of July did not produce any detectable DA levels (California Department of Health Services 1992). DA levels remained below the detection limit in 1993. Monitoring for DA has been carried out by public health agencies at this location since November 1991, and has been restricted to mussel survey only.

Our findings confirm that the mere presence of a potentially toxic Pseudonitzschia species does not necessarily give cause for concern. There are many factors that can affect DA production. The study carried out by Bates et al. (1991) on cultures of P. pungens f. multiseries demonstrated the importance of nutrient ratios in controlling toxin production and the close coupling between photosynthetic activity and DA synthesis. Their experiments showed that a source of extracellular nitrogen and light must be available in order for DA to be produced during stationary growth phase.

The fact that, to date, there have been no major DA outbreaks in the Southern California Bight leads us to hypothesize that either Pseudonitzschia australis does not produce the toxin in significant amounts, or that the toxin does not accumulate sufficiently in the water column to be transferred to higher trophic levels. Compared to the situation in Monterey Bay, nitrogen levels were lower during the period 1990 to 1993 (compare Fig. 3B in this study with Fig. 13 in Buck et al. 1992). In addition, physical factors such as circulation patterns associated with an enclosed bay do not apply to the SIO pier location. 
Acknowledgements. Phytoplankton collections were made by members of the Marine Life Research Group and most recently by P. Walker. We thank J. A. McGowan for access to temperature and nutrient data. M. Mullin made helpful comments during early stages of this manuscript, and we had fruitful discussions with M. Silver and D. Garrison. Critical reviews and helpful comments of 3 anonymous reviewers are greatly appreciated. This work was supported in part by grant \# DPP88-10462 to M.V.

\section{LITERATURE CITED}

Addison, R. F., Stewart, J. E. (1989). Domoic acid and the eastern Canadian molluscan shellfish industry. Aquaculture 77: 263-269

Allen, W. E. (1928). Review of five years of studies on phytoplankton at Southern California piers, 1920-1924, inclusive. Bull. Scripps Inst. Oceanogr. tech. Ser. 1: 357-401

Allen, W. E. (1936). Occurrence of marine plankton diatoms in a ten-year series of daily catches in Southern California. Am. J. Bot. 23: 60-63

Allen, W. E. (1940). Summary of results of twenty years of researches on marine phyytoplankton. Proc. 6th Pacif. Sci. Congr. 3: $576-583$

Allen, W. E. (1941). Twenty years' statistical studies of marine plankton dinoflagellates of Southern California. Am. Midl. Nat. 26: 603-635

Bates, S. S., Bird, C. J., de Freitas, A. S. W., Foxall, R., Gilgan, M., Hanic, L. A., Johnson, G. R., McCulloch, A. W., Odense, P., Pocklington, R., Quilliam, M. A., Sim, P. G., Smith, J. C., Subba Rao, D. V., Todd, E. C. D., Walter, J. A., Wright, J. L. C. (1989). Pennate diatom Nitzschia pungens as the primary source of domoic acid, a toxin in shellfish from eastern Prince Edward Island, Canada. Can. J. Fish. Aquat. Sci. 46: 1203-1215

Bates, S. S., de Freitas, A. S. W., Milley, J. E., Pocklington, R., Quilliam, M. A., Smith, J. C., Worms, J. (1991). Controls on domoic acid production by the diatom Nitzschia pungens f. multiseries in culture: nutrients and irradiance. Can. J. Fish. Aquat. Sci. 48: 1136-1144

Bird, C. J., Wright, J. L. C. (1989). The shellfish toxin domoic acid. Wld Aquacult. 20: 40-41

Bolin, R. L., Abbott, D. P. (1963). Studies on the marine climate and phytoplankton of the central coastal area of California, 1954-1960. Calif. coop. oceanic Fish. Invest. Rep. 9: $23-45$

Buck, K. R., Uttal-Cooke, L., Pilskaln, C. H., Roelke, D. L., Villac, M. C., Fryxell, G. A., Cifuentes, L., Chavez, F. P. (1992). Autecology of the diatom Pseudonitzschia australis Frenguelli, a domoic acid producer, from Monterey Bay, California. Mar. Ecol. Prog. Ser. 84: 293-302

California Department of Health Services, Environmental Management Branch (1992). Reports for June and July 1992. Berkeley

Fritz, L., Quilliam, M. A., Wright, J. L. C., Beale, A. M., Work, T. M. (1992). An outbreak of domoic acid poisoning attributed to the pennate diatom Pseudonitzschia australis. J. Phycol. 28: 439-442

Garrison, D. L., Conrad, S. M., Eilers, P. P., Waldron, E. M. (1992). Confirmation of domoic acid production by Pseudonitzschia australis (Bacillariophyceae) cultures. J. Phycol. 28: 604-607

Goodman, D., Eppley, R. W., Reid, F. M. H. (1984). Summer phytoplankton assemblages and their environmental correlates in the Southern California Bight. J. mar. Res. 42: 1019-1049
Hasle, G. R. (1965). Nitzschia and Fragilariopsis studied in the light and electron microscopes. II. The group Pseudonitzschia. Skr. Nor. Vidensk. Akad. Oslo 18: 1-45

Hasle, G. R. (1993). Nomenclatural notes on marine planktonic diatoms. The family Bacillariaceae. Nova Hedw. Beih. 106: 315-321

Jackson, G. A. (1986). Physical oceanography of the Southern California Bight. In: Eppley, R. W. (ed.) Plankton dynamics of the Southern California Bight. Springer-Verlag, New York, p. 13-52

Maeda, M., Kodama, T., Tanaka, T., Yoshizumi, H., Takemoto, T., Nomoto, K., Fujita, T. (1986). Structures of isodomoic acids $\mathrm{A}, \mathrm{B}$ and $\mathrm{C}$, novel insecticidal amino acids from the red alga Chondria armata. Chem. Pharm. Bull. 34: 4892-4895

Martin, J. L., Haya, K., Burridge, L. E., Wildish, D. J. (1990). Nitzschia pseudodelicatissima - a source of domoic acid in the Bay of Fundy, eastern Canada. Mar. Ecol. Prog. Ser. 67: $177-182$

Pineda, J. (1991). Predictable upwelling and the shoreward transport of planktonic larvae by internal tidal bores. Science 253: 548-551

Reid, F. M. H., Fuglister, E., Jordan, J. B. (1970). Phytoplankton taxonomy and standing crop. In: Strickland, J. D. H. (ed.) The ecology of the plankton off La Jolla, California, in the period April through September, 1967, Part V. Univ. California Press, Berkeley, p. 51-66

Reid, F. M. H., Lange, C. B., White, M. M. (1985). Microplankton species assemblages at the Scripps pier from March to November 1983 during the 1982-1984 El Niño event. Botanica mar. 28: 443-452

Smith, J. C., Cormier, R., Worms, J., Bird, C. J., Quilliam, M. A., Pocklington, R., Angus, R., Hanic, L. (1989). Toxic blooms of the domoic acid containing diatom Nitzschia pungens in the Cardigan River, Prince Edward Island, in 1988. In: Granéli, E., Sundström, B. G., Edler, L., Anderson, D. M. (eds.) Toxic marine phytoplankton. Elsevier, New York, p. 227-232

Subba Rao, D. V., de Freitas, A. S. W., Quilliam, M. A., Pocklington, R., Bates, S. S. (1989). Rates of production of domoic acid, a neurotoxic amino acid in the pennate marine diatom Nitzschia pungens. In: Granéli, E., Sundström, B. G., Edler, L, Anderson, D. M. (eds.) Toxic marine phytoplankton. Elsevier, New York, p. 413-417

Subba Rao, D. V., Quilliam, M. A., Pocklington, R. (1988). Domoic acid - a neurotoxic amino acid produced by the diatom Nitzschia pungens in culture, Can. J. Fish. Aquat. Sci. 45: 2076-2079

Todd, E. C. D. (1989). Amnesic shellfish poisoning - a new seafood toxin syndrome. In: Granéli, E., Sundström, B. G., Edler, L., Anderson, D. M. (eds.) Toxic marine phytoplankton. Elsevier, New York, p. 504-508

Tont, S. A. (1986). W. E. Allen's 20-year phytoplankton collection, Vol. I, Diatoms. University of California, Institute of Marine Resources (IMR Ref.No. 86-3)

U.S. Food and Drug Administration, Pacific Region (1992). Proceedings of the Domoic Acid Workshop, Feb. 6-8, 1992: San Pedro, CA. U.S. FDA, San Francisco

Utermöhl, H. (1958). Zur Vervollkommnung der quantitativen Phytoplankton-Methodik. Mitt. int. Verein. theor. angew. Limnol. 9: 1-38

Work, T. M., Beale, A. M., Fritz, L., Quilliam, M. A., Silver, M. W., Buck, K. R., Wright, J. L. (1993). Domoic acid intoxification of brown pelicans and cormorants in Santa Cruz, California. In: Smayda, T. J. (ed.) Fifth International Conference on Toxic Phytoplankton. Elsevier, New York, p. 643-649

Manuscript first received: July 29, 1993

Revised version accepted: November 18, 1993 